\section{Lord Rosenheim}

LoRD Rosenheim, KBE, MD, FRCP, FRS, Emeritus Professor of Medicine at University College Hospital, London, and President of the Royal College of Physicians from 1966 until March of this year, died on December 2, 1972, at the age of 64 . From 1950 to 1971 he was Professor of Medicine at London University and Director of the Medical Unit at University College Hospital Medical School.

He was knighted in 1967 and became a life peer in 1970, being created Baron Rosenheim of Camden. $\mathrm{He}$ was appointed Chairman of the Medicines Commission in January 1972 and in May was made a Fellow of the Royal Society by special election.

Max Leonard Rosenheim was born on March 15, 1908, and educated at Shrewsbury School, St John's, Cambridge, and University College Hospital, where he graduated in medicine in 1932, taking the MRCP in 1934 and proceeding MD (winning the Raymond Horton-Smith Prize) in 1938. From 1941 to 1946 he served in the RAMC, first as a medical specialist and then as consulting physician to the Allied Land Forces in South-east Asia. It was this period of his life which gave him his love of travel and his fascination with far-off countries which were to bear fruit again later.

During his undergraduate days at Cambridge he was interested in the mechanism of action of ketogenic diets which were then used for the treatment of urinary tract infections. He soon realized that beta-hydroxybutyric acid was the key metabolite and the related but more stable substance, mandelic acid, was found to be effective in treating these infections. The impact of this discovery would have been much greater had it not been for the nearly simultaneous discovery of the sulphonamides, but mandelic acid is still in clinical use. Rosenheim was also extremely interested in hypertension and was one of the first to convince the medical profession that it really was treatable.

Although these scientific advances were noteworthy, his outstanding contributions to medicine were in the clinical and administrative fields. He had high and humanitarian standards of care for patients as individuals and also a social conscience which found expression in the publication in 1970 , with Jessie Garrad, of Social Aspects of Clinical Medicine and the setting up of the Faculty of Community Medicine jointly by the three Royal Colleges of Physicians. After the war he became deeply concerned with the various boards of London University, particularly in relation to the medical curriculum and examinations and to the overseas colleges to which London University was in special relationship. As a result he became an expert committee man with his advice being much sought after. The ties abroad were strengthened by his Sims Travelling Professorship (1958) and by his work as adviser for the British Council (of which he was Chairman of the Medical Panel) which took him to Nigeria, Ceylon, the West Indies and India. On these tours he always visited out of the way places and he appeared to know everyone in the overseas universities.
It was during his Presidency of the Royal College of Physicians that he was able to exercise his qualities and his imagination to the full, and the College, in its new Lasdun home, rapidly became one of the foremost centres of postgraduate medical education. Max went everywhere, and while politically we were losing an empire, medically we were gaining one. $\mathrm{He}$ persuaded the three Royal Colleges of Physicians to drop multipie diplomatosis and to unite in a common Membership examination -MRCP(UK). The MCQ paper of Part I of this examination became outstandingly successful and applications to take it came in from Ceylon, Egypt, Ghana, Iran, Malaysia and the West Indies. Under him the College appeal was launched, which reached its target of $£ 500,000$, and it is still being used for a number of research and other College activities, the best known of which is the campaign on smoking and health. $\mathrm{He}$ also started the practice of holding College lectures in provincial centres.

Lord Rosenheim was unmarried, and in spite of his distinguished position he lived an unpretentious life and was held in the greatest affection by all who knew him. $\mathrm{He}$ had innumerable friends whom he used to delight with his amusing and stimulating conversationnot only on medical matters but on books, music and fishing, which were his second loves. For many years he lived with his mother, to whom he was very devoted and who died only recently. Although 1972 brought in a new era for him he seemed just as buoyant as ever and ready for new ventures, but it was not to be, and by his death British medicine is the poorer.

\section{HOW TO BUY NATURE}

The cost of one year's subscription to NATURE is :

$$
\text { UK \& elsewhere }
$$

US \& Canada

Nature (Friday)

$£ 16$

$\$ 48$

Nature \& Nature Physical Science

or Nature New Biology

f24

$\$ 83$

Nature New Biology or Nature

Physical Science

$£ 10$

$\$ 35$

All three editions

$£ 29.50$

$\$ 108$

(Charges for delivery by air mail on application). Subscribers in North America may be able to claim a tax rebate against their NATURE subscription.
Editorial, Advertising and Publishing Offices of NATURE

MACMILLAN JOURNALS LIMITED

4 LITTLE ESSEX STREET, LONDON WC2R 3 LF

Telephone Number: 01-836 6633. Telegrams: Phusis London WC2R 3LF Telex 262024

MACMILLAN JOURNALS LIMITED

711 NATIONAL PRESS BUILDING

WASHINGTON DC 20004

Telephone Number : 202-737 2355. Telex 64280

International Advertisement Manager PETER R. KAVANAGH

MACMILLAN JOURNALS LIMITED

4 LITTLE ESSEX STREET, LONDON WC2R 3LF

Telephone Numbers: UK 01-836 6633. USA 202-737 2355

Subscription Department MACMILLAN JOURNALS LIMITED

BRUNEL ROAD, BASINGSTOKE, HANTS RG21 2XS

Telephone Number: Basingstoke 29242

Classified advertisements

T. G SCOTT \& SON, LIMITED

1 CLEMENT'S INN, LONDON WC2A 2ED

Telephone Number: 01-242 6264/01-405 4743

Telegrams: Textualist London WC2A 2ED

Registered as a newspaper at the Post Office

Copyright (C) Macmillan Journals Limited, March 21973 